\title{
PERBEDAAN GAYA HIDUP SEHAT DAN SIKAP TERHADAP MAKANAN ORGANIK DARI GENERASI BABY BOOMERS, X, DAN Y DI SURABAYA
}

\author{
Surya Nika Suharjo ${ }^{1}$, Agung Harianto ${ }^{2}$ \\ ${ }^{1,2}$ Program Manajemen Perhotelan, Program Studi Manajemen, Fakultas Ekonomi, Universitas Kristen Petra \\ Jl. Siwalankerto 121-131, Surabaya, Indonesia \\ Email: surya_nikasuharjo@yahoo.co.id'; agung.harianto@petra.ac.id²
}

\begin{abstract}
Abstrak
Penelitian ini bertujuan untuk melihat perbedaan gaya hidup sehat dan sikap terhadap makanan organik diantara generasi Baby Boomers, X, dan Y. Teknik pengumpulan data menggunakan kuesioner dan dinilai menggunakan 5 point skala likert. Teknik analisa yang digunakan adalah uji ANOVA dan uji Post Hoc dengan jumlah sampel sebanyak 224 responden. Hasil penelitian ini adalah terdapat perbedaan yang signifikan antara generasi Baby Boomers, X, dan Y pada variabel gaya hidup sehat, sedangkan pada variabel sikap terhadap makanan organik hanya generasi Baby Boomers dan generasi Y yang memiliki perbedaan.
\end{abstract}

Kata kunci: Gaya hidup sehat; sikap terhadap makanan organik; generasi baby boomers; generasi X; generasi Y.

\begin{abstract}
This study aims to look at differences in healthy lifestyles and attitudes towards organic food among generations of Baby Boomers, $X$, and $Y$. Data collection techniques used questionnaires and assessed using 5 point likert scale. The analysis technique used is the ANOVA and Post Hoc test with a total sample of 224 respondents. The results of this study are that there are significant differences between Baby Boomers, $X$, and $Y$ generation on healthy lifestyle variable, however in the attitudes toward organic foods variable only Baby Boomers generation and $Y$ generation have differences.
\end{abstract}

Keywords: Healthy lifestyle; attitudes toward organic foods; baby boomers generation; X generation; Y generation.

\section{PENDAHULUAN}

Seiring dengan perkembangan jaman dan perkembangan teknologi yang terjadi, masyarakat pun mulai mengalami perubahan dalam gaya hidup. Menurut Didno (2017), saat ini masyarakat Indonesia lebih suka mengonsumsi makanan cepat saji, serba praktis, dan menyukai makanan yang mengandung lemak. Terlebih dengan jarang melakukan aktivitasaktivitas yang dapat menjadikan tubuh menjadi lebih sehat, seperti olahraga atau jalan kaki membuat masyarakat Indonesia sering terkena penyakit. Perubahan gaya hidup masyarakat menjadi gaya hidup yang tidak sehat, kurangnya aktifitas fisik dan kebiasaan makan yang tidak baik mengakibatkan pergeseran dari penyakit yang menular menjadi penyakit tidak menular seperti obesitas, kanker paru-paru, jantung, gangguan pencernaan, stroke, dan kerusakan tubuh lainnya yang bisa menyebabkan kematian.

Menurut Rafikasari (2018), berdasarkan data sebuah survei yang dirilis pada akhir 2016 oleh Nielsen's New Global Health and Ingredient-Sentiment Survey mengenai pola makan masyarakat modern di Indonesia menunjukkan, 70\% responden mengaku menjalani diet tertentu untuk menghindari berbagai penyakit degeneratif dan $68 \%$ responden mulai berinvestasi lebih pada makanan dengan kandungan yang sesuai dengan diet mereka. Survei ini menunjukkan bahwa masyarakat Indonesia semakin sadar akan kesehatan, dimulai dengan menerapkan pola hidup dan pola makan yang lebih sehat dibarengi dengan meningkatnya kesadaran akan risiko penyakit degeneratif yang timbul akibat gaya hidup yang kurang sehat.

Chen (2009) dalam penelitiannya di Taiwan menyatakan bahwa konsumen sudah lebih sadar akan kandungan nutrisi, kesehatan, dan kualitas makanan yang di konsumsi, dan faktor kesehatan menjadi kriteria penting dalam mengonsumsi makanan. Hal ini menyebabkan permintaan akan makanan organik meningkat, karena konsumen menganggap bahwa makanan organik dijamin lebih sehat dan aman daripada makanan konvensional. Gaya hidup juga menjadi faktor yang mempengaruhi dalam keputusan pembelian makanan. Konsumen yang memiliki gaya hidup sehat (healthy lifestyle) dinyatakan akan berpengaruh lebih signifikan terhadap sikap konsumen pada makanan organik. Hal ini dikarenakan walaupun 
seseorang memiliki health consciousness dan mungkin siap untuk melakukan hal-hal yang baik untuk kesehatan, atau ketika seseorang memiliki kepedulian terhadap lingkungan, sikap positif terhadap makanan organik tidak akan terbentuk dengan mudah jika konsumen tidak menjalankan aktivitas fisik yang merupakan gaya hidup sehat. Dengan kata lain, konsumen yang peduli untuk menjaga kesehatan dengan berolahraga, diet, menjaga kadar garam yang dikonsumsi, menjalani pengecekan medis secara berkala dapat meningkatkan hubungan positif terhadap sikap konsumen pada makanan organik.

Di sisi lain Hawkins dan Mothersbaugh (2010) menyatakan bahwa umur mempengaruhi gaya hidup dan konsep diri, sehingga penempatan produk yang sesuai dengan umur sangat penting, karena umur juga dapat mempengaruhi konsumsi produk mulai dari makanan, perlengkapan sampai liburan. Umur membentuk media apa yang digunakan individu, dimana individu berbelanja, bagaimana individu menggunakan suatu produk, dan bagaimana pikiran dan perasaan individu tentang aktivitas pemasaran. Pengelompokan berdasarkan umur atau tahun kelahiran menghasilkan teori generasi. Kelompok generasi yang akan digunakan dalam penelitian kali ini adalah generasi Baby Boomers (tahun 1946-1964), generasi X (tahun 1965-1980) dan generasi Y (tahun 19811999) (Lancaster \& Stillman, 2002).

Paul \& Rana (2012) dalam penelitiannya juga menemukan bahwa keputusan pembelian konsumen terhadap makanan organik dapat dipengaruhi oleh beberapa faktor yaitu demografi, pengaruh akan kesehatan, dan ketersediaan. Faktor demografi yang berpengaruh adalah tingkat pendidikan, dimana konsumen yang memiliki tingkat pendidikan yang semakin tinggi akan cenderung untuk membeli makanan organik. Manfaat untuk kesehatan juga merupakan faktor yang membuat konsumen mengonsumsi makanan organik, disamping harga makanan organik yang dianggap mahal tetapi pada saat yang sama konsumen juga percaya bahwa harga mahal yang dibayarkan sebanding dengan manfaat kesehatan yang diperoleh.

Di sisi lain Hawkins dan Mothersbaugh (2010) menyatakan bahwa umur mempengaruhi gaya hidup dan konsep diri, sehingga penempatan produk yang sesuai dengan umur sangat penting, karena umur juga dapat mempengaruhi konsumsi produk mulai dari makanan, perlengkapan sampai liburan. Umur membentuk media apa yang digunakan individu, dimana individu berbelanja, bagaimana individu menggunakan suatu produk, dan bagaimana pikiran dan perasaan individu tentang aktivitas pemasaran. Pengelompokan berdasarkan umur atau tahun kelahiran menghasilkan teori generasi. Kelompok generasi yang akan digunakan dalam penelitian kali ini adalah generasi Baby Boomers (tahun 1946-1964), generasi X (tahun 1965-1980) dan generasi Y (tahun 19811999) (Lancaster \& Stillman, 2002).

Penulis melakukan pra-survey untuk melihat lebih dalam fenomena yang akan diteliti. Dengan jumlah responden 20 orang, 10 dari generasi $\mathrm{X}$ dan 10 dari Generasi Y didapatkan hasil sebagai berikut: semua responden setuju bahwa memiliki gaya hidup sehat merupakan hal yang penting, dimana $75 \%$ responden setuju bahwa dari tiga pilihan aktivitas yang dijabarkan, mengonsumsi makanan sehat merupakan hal yang paling utama untuk dilakukan dalam menjalani gaya hidup sehat, dilanjutkan dengan berolahraga secara teratur dan menjalani cek kesehatan secara berkala. Dari 20 responden, 95\% responden mengetahui tentang makanan organik, $70 \%$ mengaku pernah mengonsumsi makanan organik, $75 \%$ menyatakan setuju bahwa makanan organik lebih sehat daripada makanan konvensional. Tingkat intensitas konsumsi responden berbeda-beda, mulai dari satu minggu sekali sampai dua kali dalam sebulan. Alasan terbanyak responden dalam mengonsumsi makanan organik adalah karena makanan organik lebih sehat, bebas dari pestisida, dan berasal dari bahan yang alami. Alasan lainnya adalah karena disediakan oleh orang tua, diet, dan rasa ingin mencoba. Dari hasil pra-survey ini menyatakan bahwa sikap responden terhadap makanan organik adalah positif dengan menyatakan bahwa makanan organik lebih sehat dan aman bagi tubuh.

Dengan adanya fenomena perubahan gaya hidup masyarakat Indonesia yang mulai menjalani gaya hidup sehat dengan mengonsumsi makanan organik, maka penulis ingin meneliti bagaimana gaya hidup sehat dan sikap terhadap makanan organik pada masyarakat Surabaya dalam tiga kelompok generasi, yaitu generasi Baby Boomers, generasi $\mathrm{X}$ dan generasi $\mathrm{Y}$, dan juga meneliti ada atau tidaknya perbedaan antar generasi.

\section{TINJAUAN PUSTAKA}

\section{Makanan Organik}

Menurut Paul dan Rana (2012) makanan organik adalah makanan yang aman bagi lingkungan, diproduksi dengan menggunakan metode yang ramah lingkungan yang tidak melibatkan bahan sintesis modern seperti pestisida dan pupuk kimia, tidak mengandung organisme hasil rekayasa genetika dan zat aditif makanan. Blair (2012) mengatakan kata organik dalam konteks makanan digunakan untuk mendeskripsikan makanan yang telah diproduksi 
dengan cara yang spesial, yaitu secara organik. Organic farming adalah metode produksi yang dimaksudkan agar sustainable dan harmonis dengan lingkungan. Metode ini melarang penggunaan pupuk dan pestisida sintesis, produk-produk yang diproduksi dengan modifikasi gen, iradiasi sebagai proses pengawetan, lumpur limbah sebagai pupuk, dan bahan kimia. Perbedaan utama antara pertanian organik dan konvensional adalah tidak adanya penggunaan pupuk kimia atau pestisida kimia yang digunakan untuk hasil panen organik dan hewan ternak yang dipelihara secara organik harus diberi makan dengan bahan makanan alami atau organik.

Konsumen merasa makanan organik lebih sehat, memiliki kualitas dan keamanan lebih daripada makanan konvensional karena diproduksi dengan pertanian organik (Chen, 2009 ;Blair, 2012).

\section{Teori Generasi}

Generasi atau kelompok umur (age cohort) adalah sekelompok individu yang telah mengalami lingkungan sosial, politik, sejarah, dan ekonomi yang sama. Analisa cohort adalah proses mendeskripsikan dan menjelaskan sikap, nilai-nilai, dan perilaku dalam suatu kelompok umur yang juga memprediksi sikap, nilai-nilai, dan perilakunya di masa mendatang (Hawkins dan Mothersbaugh, 2010).

Generasi Baby Boomers adalah individu yang lahir diantara tahun 1946-1964. Generasi ini punya sikap yang optimis, percaya pada adanya peluang, seringkali terlalu idealis untuk membuat perubahan positif didunia, juga kompetitif dan mencari cara untuk melakukan perubahan dari sistem yang sudah ada (Lancaster \& Stillman, 2002). Dalam hal karakteristik, gaya hidup, dan sikap menurut Williams \& Page (2011), generasi Baby Boomers merupakan generasi yang paling banyak dan berpengaruh. Generasi ini menetapkan diri pada karir dan kebanyakan adalah workaholic. Generasi ini melihat pekerjaan sebagai bentuk pencapaian diri, status, dan pembuktian diri, sehingga jabatan dalam pekerjaan sangat penting. Generasi ini juga diantisipasi akan bekerja lebih lama dari generasi sebelumnya. Kesehatan, energi, dan kemakmuran adalah tujuan utama generasi Baby Boomer. Generasi ini mungkin sudah mulai menua, tetapi generasi ini tidak suka diingatkan akan hal itu. Generasi ini tidak suka jika dipanggil dengan sebutan yang memiliki arti kata tua, oleh karena generasi ini mencari alternatif supaya dapat terlihat lebih muda. Makanan alami dan organik penting bagi generasi ini.

Generasi $\mathrm{X}$ adalah individu yang lahir diantara tahun 1965-1980. Generasi ini mempunyai sikap yang skeptis, tertutup, sangat independen dan punya potensi, tidak bergantung pada orang lain untuk menolong mereka (Lancaster \& Stillman, 2002). Dalam hal karakteristik, gaya hidup, dan sikap menurut Williams \& Page (2011), generasi X selalu mendahulukan keluarga. Generasi $\mathrm{X}$ ingin menyeimbangkan antara keluarga, kehidupan, dan pekerjaan. Kesuksesan menjadi hal yang tidak pasti bagi generasi ini. Generasi $X$ tidak percaya mengorbankan waktu, energi, dan hubungan untuk kemajuan seperti generasi Baby Boomers. Generasi ini mempunyai pemikiran bahwa kerja keras adalah suatu keharusan. Generasi ini juga tidak sabaran dan materialistis. Generasi X adalah individu yang bebas. Generasi ini lebih suka untuk berwirausaha dan tidak akan bergantung pada perusahaan dalam jangka waktu yang lama. Informasi dan teknologi penting untuk generasi ini. Generasi X adalah generasi yang lebih visual, lebih sedikit membaca, dan mengunjungi galeri seni lebih sering dari generasi lain. Keanekaragaman dan berpikir secara global adalah inti nilai-nilai generasi ini.

Generasi Y adalah individu yang lahir diantara tahun 1981-1999. Generasi ini mempunyai sikap yang realistis, sangat menghargai perbedaan, lebih memilih bekerja sama daripada menerima perintah, dan sangat pragmatis ketika memecahkan persoalan (Lancaster \& Stillman, 2002). Karakteristik, gaya hidup, dan sikap menurut Williams \& Page (2011), generasi Y meliputi remaja dan dewasa muda. Generasi $\mathrm{Y}$ egois dan mandiri, tegas, emosional dan ekspresif secara intelektual, dan suka mempertanyakan segalanya. Generasi ini juga terus terang dan ekspresif, mudah beradaptasi dan merasa nyaman dalam berbagai keadaan, tidak mengenal rasa takut dan hidup untuk hari ini. Generasi Y memiliki kebutuhan yang besar akan pengakuan teman sebaya atau orang-orang disekitarnya sehingga mempengaruhi pilihan produk dan merk yang dikonsumsi. Internet adalah taman bermain bagi generasi ini. Generasi Y paham akan internet dan dapat menggunakan e-mail, handphone, dan pesan teks untuk berkomunikasi. Generasi Y adalah individu yang dapat melakukan multi-tasking secara efisien. Generasi ini mampu memahami konsep-konsep baru dan berorientasi pada pembelajaran. Perubahan adalah hal yang normal. Generasi Y inovatif, ingin tahu, dan belajar sepanjang hidup. Generasi Y berorientasi terhadap tujuan, sangat termotivasi terhadap persepsi kesuksesan, dan sudah merencanakan untuk menikah dan berkeluarga. Generasi ini merespon dengan baik hal-hal yang berhubungan dengan kehidupan ramah lingkungan dan efisiensi energi. 


\section{Gaya Hidup Sehat}

Kotler dan Armstrong (2016) mengidentifikasikan gaya hidup sebagai pola hidup seseorang yang diekspresikan dalam aktivitas, minat dan opininya. Gaya hidup sehat adalah cara hidup seseorang yang meminimalisir resiko terkena penyakit serius atau kematian dini (World Health Organization, 1999). Gaya hidup sehat juga didefinisikan sebagai orientasi terhadap pencegahan masalah kesehatan dan pemaksimalan kesejahteraan pribadi (Bloch dalam Divine \& Lepisto, 2005). Penelitian tentang analisa gaya hidup sehat konsumen yang dilakukan oleh Divine \& Lepisto (2005), memberikan hasil bahwa jenis kelamin, tingkat pendidikan, dan umur bisa menjadi prediktor yang signifikan. Wanita, konsumen dengan tingkat pendidikan yang tinggi dan konsumen dengan umur yang lebih tua akan lebih mungkin dalam menjalani gaya hidup sehat. Selain itu indikator penting yang menunjukkan apakah seseorang menjalani gaya hidup sehat adalah konsumsi buah dan sayur dan kegiatan olahraga.

Gil et al., dalam Chen (2009) menyatakan bahwa gaya hidup sehat menekankan aktivitasaktivitas yang berhubungan dengan kesehatan fisik seperti (1) mengonsumsi makanan alami (natural food consumption) yang berhubungan dengan konsumsi buah dan sayuran segar dan kesadaran untuk mengurangi konsumsi daging, makanan olahan dan makanan dengan bahan kimiawi ;(2) perawatan kesehatan (health care) yang menunjukkan minat konsumen untuk menjaga dirinya tetap sehat, melalui olahraga, diet, menjaga kadar garam yang dikonsumsi juga melakukan cek kesehatan secara berkala ; dan (3) keseimbangan hidup (life equilibrium) yang menunjukkan adanya ketertarikan konsumen dalam menjaga keseimbangan antara pekerjaan dan kehidupan pribadi, hidup dalam cara yang teratur dan mencoba untuk mengurangi stres. Sehingga tiga hal inilah yang akan menjadi indikator untuk menilai gaya hidup sehat seseorang.

\section{Sikap terhadap Makanan Organik}

Sikap adalah evaluasi, perasaan, dan kecenderungan individu terhadap suatu objek atau benda yang relatif konsisten. Sikap menempatkan individu dalam kerangka pemikiran mengenai rasa suka atau tidak suka, mendekati atau menjauhi sesuatu (Kotler dan Armstrong, 2016, p. 181). Pembentukan sikap konsumen sangat dipengaruhi oleh pengalaman pribadi, pengaruh keluarga dan teman-teman, pemasaran langsung dan media massa (Schiffman dan Kanuk, 2007). Sikap konsumen disini adalah sikap konsumen terhadap makanan organik yang berarti evaluasi, perasaan, dan kecenderungan individu terhadap makanan organik. Makanan organik dipasarkan sebagai makanan yang lebih sehat dan ramah lingkungan daripada makanan konvensional. Konsumen percaya bahwa makanan organik lebih sehat dan menjanjikan perlindungan lingkungan yang lebih baik. Sehingga sikap konsumen terhadap makanan organik digolongkan dalam beberapa aspek, yaitu (1) aspek kualitas dan kesehatan (quality and healthy aspect) dimana menekankan pada kualitas, kesehatan, dan tidak adanya efek yang membahayakan; (2) penampilan luar (external appearance) yang berhubungan dengan rasa dan kemenarikan makanan organik, dan (3) aspek negatif (negative aspect) yang berhubungan dengan persepsi bahwa makanan organik hanya sebuah tren baru dan memiliki harga lebih mahal daripada makanan konvensional ( Gil et al., dalam Chen (2009)).

\section{Penelitian Terdahulu}

Perbedaan umur atau tahun kelahiran yang menyebabkan adanya pengelompokan individu dalam beberapa generasi mewakili bahwa setiap kelompok generasi mempunyai sikap, nilai-nilai, dan perilaku yang berbeda. Hal ini ditunjukkan dalam karakteristik setiap generasi yang berbeda dalam menjalani kehidupan. Sebagai contoh, setiap generasi mempunyai persepsi yang unik dalam pekerjaan, tergantung kepada karakteristik yang dimiliki. Perbedaan lainnya terdapat pada berbelanja dan perilaku dalam menyiapkan makanan antar kelompok umur. Anak muda tiga kali lebih mungkin untuk menyiapkan makanan dari makanan beku atau makanan siap saji dan lima kali lebih mungkin untuk membeli pulang makanan jadi dibandingkan dengan yang berumur 60 tahun atau lebih. Generasi $\mathrm{Y}$ dan generasi $\mathrm{X}$ cenderung menggunakan makanan siap saji selama hari biasa dan pada saat akhir pekan akan bereksperimen dengan resep baru dan bahan makanan segar, hal ini dikarenakan waktu yang terbatas untuk digunakan dalam hal lain. Sedangkan generasi Baby Boomers lebih memiliki lebih banyak waktu untuk menyiapkan makanan sehingga generasi ini cenderung menggunakan bahan makanan yang segar dan menghindari makanan cepat saji (Hunter \& Worsley, 2009).

Penelitian yang dilakukan di Itali oleh Casini et al., (2015) tentang perubahan tren konsumsi pada generasi X dari tahun 2001 hingga tahun 2011 mendapatkan hasil bahwa muncul satu pola konsumsi baru, yang disebut "healthier consumers". Konsumen dalam segmen ini ditandai dengan tingginya tingkat konsumsi buah dan sayuran, roti dan gandum, tingkat konsumsi ikan yang sedang, dan tingkat konsumsi daging, lemak, alkohol dan makanan manis yang rendah. 
Terdapat perbedaan antara produk dan jasa yang digunakan oleh setiap generasi (Williams \& Page, 2011). Produk dan jasa yang penting bagi Generasi Baby Boomers adalah makanan sehat, produk yang berkaitan dengan kesehatan seperti spa, botox, perawatan untuk kebotakan. Generasi Baby Boomers tertarik kepada produk dan teknologi yang memudahkan hidup, menghemat waktu, dan tidak menguras uang. Namun, generasi Baby Boomers saat ini berumur di atas 50 tahun dimana generasi ini sudah berada di masa tua. Generasi Baby Boomers terus mengalamai keadaan ekonomi yang baik sehingga membuat generasi ini menjadi generasi spenders, yang diperkirakan secara signifikan akan rela membayar untuk perawatan kesehatan (Berkowitz \& Schewe, 2011). Untuk generasi X mereka perlu membeli produk dan jasa untuk membangun rumah tangga dan keluarga, seperti mobil, peralatan rumah tangga dan kebutuhan anak. Sedangkan untuk generasi $\mathrm{Y}$, produk yang penting meliputi pakaian, aksesoris, sepatu, peralatan olahraga, dan hiburan.

Generasi Baby boomers penuh dengan individu yang sibuk, workaholic, dan mempunyai ekspektasi yang tinggi. Pekerjaan dan pengorbanan kehidupan pribadi bagi generasi ini setara dengan kesuksesan finansial yang dicapai (Gilley et al., 2015). Generasi $\mathrm{X}$ berfokus dalam keseimbangan antara kehidupan pribadi dan pekerjaan, generasi ini mempunyai prinsip bekerja untuk hidup, bukan hidup untuk bekerja (Kapoor \& Solomon, 2011). Begitu juga dengan generasi $\mathrm{Y}$ yang mencari pekerjaan yang memberikan keseimbangan antara pekerjaan dan kehidupan pribadi sehingga karyawan mempunyai kepuasan kerja yang tinggi. Generasi Y tidak bersedia untuk mengorbankan kehidupan pribadi demi karir, dan mencari pekerjaan yang dapat memberikan fleksibilitas antara bekerja dan bermain (Gilley et al., 2015). Berdasarkan penelitian-penelitian tersebut, maka penulis dapat menyusun hipotesis sebagai berikut :

H1: Terdapat perbedaan gaya hidup sehat antara generasi Baby boomers, generasi $\mathrm{X}$, dan generasi Y di Surabaya.

Dalam menjaga kesehatan, generasi Baby boomers menganggap penting untuk mengonsumsi makanan alami dan organik (Williams \& Page, 2011). Penelitian yang dilakukan oleh Ntanos et al., (2014) menyebutkan generasi $\mathrm{Y}$ atau bisa juga disebut sebagai generasi milenial tampak sebagai generasi yang membeli makanan organik dan rela untuk membayar lebih untuk membeli makanan organik. Makanan organik yang paling banyak dibeli oleh generasi $\mathrm{Y}$ adalah buah-buahan dimana kriteria yang penting dalam membeli makanan organik adalah kualitas, sertifikasi, rasa, variasi, dan nama perusahaan. Dimitri \& Dettmann (2012) menyatakan bahwa konsumen yang sudah berkeluarga dan atau yang sudah memiliki anak akan lebih mungkin untuk mengonsumsi makanan organik. Dari penelitianpenelitian sebelumnya menyatakan bahwa dapat terjadi perbedaan gaya hidup sehat antara generasi Baby boomers, generasi $\mathrm{X}$ dan generasi $\mathrm{Y}$. Chen (2009) dalam penelitiannya menyatakan adanya hubungan antara gaya hidup sehat dan sikap terhadap makanan organik. Konsumen yang peduli untuk menjaga kesehatan dengan berolahraga, diet, menjaga kadar garam yang dikonsumsi, menjalani pengecekan medis secara berkala dapat meningkatkan hubungan positif terhadap sikap konsumen pada makanan organik. Oleh karena hal ini penulis dapat menyimpulkan bahwa perbedaan gaya hidup sehat antara generasi bisa menyebabkan perbedaan juga pada sikap terhadap makanan organik.Berdasarkan penelitian-penelitian tersebut, maka penulis dapat menyusun hipotesis sebagai berikut:

H2: Terdapat perbedaan sikap terhadap makanan organik antara generasi Baby boomers, generasi $\mathrm{X}$, dan generasi $\mathrm{Y}$ di Surabaya.

\section{METODE PENELITIAN}

Jenis penelitian yang digunakan adalah penelitian kuantitatif dengan pendekatan komparatif. Populasi yang digunakan dalam penelitian ini adalah masyarakat Surabaya atau masyarakat yang tinggal di Surabaya yang pernah mengonsumsi makanan organik. Teknik sampling yang digunakan adalah teknik non probability sampling yaitu quota sampling. Adapun sampel dalam penelitian ini adalah masyarakat Surabaya atau yang bertempat tinggal di Surabaya dan pernah mengonsumsi makanan organik, memiliki kriteria usia yang sesuai dengan usia generasi Baby Boomers ( tahun 1946 - 1964), generasi X (tahun 1965 - 1980) dan generasi Y (tahun 1981 - 1999). Pada tahun 2018 usia generasi Baby Boomers adalah 54 tahun -72 tahun, usia generasi $X$ adalah 38 tahun -53 tahun, dan usia generasi $Y$ adalah 19 tahun -37 tahun.

Metode dan prosedur pengumpulan data primer dalam penelitian ini dilakukan dengan menyebarkan kuesioner secara offline dan online selama bulan Desember 2018. Kuesioner yang dibagikan merupakan kuesioner tertutup dengan close ended question dimana alternatif jawabannya telah disediakan oleh penulis. Responden akan diminta untuk memberi pendapat tentang serangkaian pernyataan yang berhubungan dengan variabel yang sedang diteliti. Skala 
pengukuran yang akan digunakan adalah 5-point Likert Scale. Dari penyebaran kuesioner yang dilakukan, didapatkan total 224 sampel dengan 50 sampel generasi Baby Boomers, 54 sampel generasi X, dan 120 sampel generasi Y.

Pada penelitian ini, pengolahan data menggunakan teknik analisa statistik deskriptif dan analisa statistik komparatif. Pada teknik analisa statistik deskriptif, penulis membandingkan nilai rata-rata variabel gaya hidup sehat dan sikap terhadap makanan organik untuk memberikan gambaran atau deskripsi tentang perbedaan antar generasi. Pada teknik analisa statistik komparatif, penulis menggunakan uji One Way Anova dan Post Hoc Test untuk mengetahui dan menunjukkan perbedaan yang terjadi antar generasi dan menguji hipotesis.

\section{HASIL PENELITIAN DAN PEMBAHASAN}

\section{Deskripsi Profil Responden}

Tabel 1 menunjukkan identitas responden dari segi usia, jenis kelamin dan jenis pekerjaan. Secara keseluruhan mayoritas responden yang didapat dalam penelitian ini adalah responden perempuan dengan total 134 responden. Mayoritas pekerjaan responden dengan persentase $42 \%$ adalah pelajar/mahasiswa.

Menurut data tabel 2 jenis makanan organik yang paling banyak dikonsumsi oleh generasi Baby Boomers, generasi X dan generasi $\mathrm{Y}$ adalah sayuran. Mayoritas generasi Baby Boomers membeli makanan organik di supermaket, dengan persentase $44 \%$ dan di pasar tradisional dengan persentase $42 \%$. Begitu pula dengan generasi $\mathrm{X}$, mayoritas membeli makanan organik di pasar tradisional sebanyak 37\% dan supermarket sebanyak $35 \%$. Sedangkan generasi Y mayoritas responden membeli makanan organik di supermarket, dengan persentase $65 \%$. Secara keseluruhan, responden paling sering membeli makanan organik di supermarket dengan persentase 53\%, diikuti dengan membeli di pasar tradisional sebesar $26 \%$, di restoran sebanyak $12 \%$, membeli secara online sebanyak $5 \%$, dan membeli di toko organik, mendapat dari orang lain dan menanam sendiri masing-masing sebanyak $1 \%$.

Mayoritas generasi Baby Boomers sebanyak $44 \%$ mengonsumsi makanan organik minimal 1 kali dalam semingggu. Sebanyak 26\% mengonsumsi makanan organik minimal 2-3 kali dalam seminggu dan sebanyak 30\% responden tidak mengonsumsi makanan organik secara rutin. Pada generasi X, mayoritas generasi $\mathrm{X}$ sebanyak $61 \%$ juga mengkonsumsi makanan organik minimal 1 kali dalam seminggu. Sebanyak 22\% mengonsumsi makanan organik minimal 2-3 kali dalam seminggu dan sebanyak $17 \%$ tidak mengonsumsi secara teratur. Sedangkan generasi Y, mayoritas sebanyak $40 \%$ tidak mengonsumsi makanan organik secara teratur, sebanyak 34\% mengonsumsi minimal 1 kali seminggu dan 26\% mengonsumsi minimal 2-3 kali dalam seminggu. Secara keseluruhan, mayoritas responden mengonsumsi makanan organik minimal 1 kali dalam seminggu.

Mayoritas responden dari generasi Baby Boomers sebanyak $98 \%$, generasi $X$ sebanyak $91 \%$ dan generasi Y sebannyak $89 \%$ menyatakan akan membeli ulang makanan organik. Sehingga dapat disimpulkan minat beli ulang makanan organik dari setiap generasi sangat tinggi.

\section{Analisa Statistik Deskriptif}

Analisa statistik deskriptif variabel penelitian dari tanggapan responden bertujuan untuk menggambarkan tanggapan responden terhadap pernyataanpernyataan dalam kuesioner dari masing-masing variabel. Indikator-indikator yang digunakan dalam variabel gaya hidup sehat terbagi menjadi natural food consumption, health care, dan life equilibrium. Indikator-indikator yang digunakan dalam variabel sikap terhadap makanan organik terbagi menjadi quality and healthy aspect, external appearnace, dan negative aspect.

Pada indikator Natural Food Consumption, nilai rata-rata tertinggi pada generasi Baby Boomers, generasi $\mathrm{X}$ dan generasi $\mathrm{Y}$ adalah pada pernyataan sering mengonsumsi buah dan sayur. Tetapi selain sering mengonsumsi buah dan sayur generasi Baby Boomers juga sangat menghindari mengonsumsi produk makanan yang mengandung bahan kimia tambahan. Sedangkan nilai rata-rata terendah ada pada pernyataan "saya adalah seorang vegetarian", yang artinya mayoritas generasi Baby Boomers, generasi $\mathrm{X}$, dan $\mathrm{Y}$ bukan seorang vegetarian.

Pada indikator Health Care, generasi Baby Boomers lebih rutin dalam melakukan pemeriksaan kesehatan dibandingkan generasi lainnya, sedangkan generasi $\mathrm{X}$ dan $\mathrm{Y}$ lebih rutin melakukan olahraga secara teratur dalam menjaga kesehatan tubuhnya. Sedangkan nilai rata-rata terendah ada pada pernyataan " saya mengikuto diet rendah garam", yang artinya mayoritas generasi Baby Boomers, generasi X, dan Y belum terlalu memperhatikan kadar garam dalam menjaga kesehatan.

Pada indikator Life Equilibrium, generasi Baby Boomers dan generasi Y lebih mencoba untuk memiliki gaya hidup yang teratur, sedangkan generasi $\mathrm{X}$ lebih mencoba menyeimbangkan antara pekerjaan dan kehidupan pribadi. 
Tabel 1.. Profil Responden

\begin{tabular}{lcccccccc}
\hline \multirow{2}{*}{ Jenis Kelamin } & \multicolumn{2}{c}{ Generasi Baby Boomers } & \multicolumn{2}{c}{ Generasi X } & \multicolumn{2}{c}{ Generasi Y } & \multicolumn{2}{c}{ Total } \\
\cline { 2 - 9 } & Jumlah & $\mathbf{\%}$ & Jumlah & $\mathbf{\%}$ & Jumlah & \% & Jumlah & \% \\
\hline Laki-Laki & 25 & $50 \%$ & 26 & $48 \%$ & 39 & $33 \%$ & 90 & $40 \%$ \\
Perempuan & 25 & $50 \%$ & 28 & $52 \%$ & 81 & $68 \%$ & 134 & $60 \%$ \\
Total & 50 & $100 \%$ & 54 & $100 \%$ & 120 & $100 \%$ & 224 & $100 \%$ \\
\hline Jenis Pekerjaan & & & & & & & & \\
Pelajar/Mahasiswa & 0 & $0 \%$ & 0 & $0 \%$ & $\mathbf{9 3}$ & $\mathbf{7 8 \%}$ & 93 & $\mathbf{4 2 \%}$ \\
Wiraswasta & $\mathbf{2 5}$ & $\mathbf{5 0 \%}$ & 16 & $30 \%$ & 11 & $9 \%$ & 52 & $23 \%$ \\
Ibu Rumah Tangga & 18 & $36 \%$ & $\mathbf{1 9}$ & $\mathbf{3 5 \%}$ & 2 & $2 \%$ & 39 & $17 \%$ \\
Pegawai Swasta & 5 & $10 \%$ & 17 & $31 \%$ & 14 & $12 \%$ & 36 & $16 \%$ \\
Pegawai Negeri & 0 & $0 \%$ & 1 & $2 \%$ & 0 & $0 \%$ & 1 & $0 \%$ \\
Profesional & 0 & $0 \%$ & 1 & $2 \%$ & 0 & $0 \%$ & 1 & $0 \%$ \\
Pensiunan & 2 & $4 \%$ & 0 & $0 \%$ & 0 & $0 \%$ & 2 & $1 \%$ \\
\hline Total & 50 & $100 \%$ & 54 & $100 \%$ & 120 & $100 \%$ & 224 & $100 \%$ \\
\hline
\end{tabular}

Tabel 2. Jenis Makanan Organik yang Pernah di Konsumsi Responden

\begin{tabular}{ccccccccc}
\hline Jenis Makanan & \multicolumn{2}{c}{ Generasi Baby Boomers } & \multicolumn{2}{c}{ Generasi X } & \multicolumn{2}{c}{ Generasi Y } & \multicolumn{2}{c}{ Total } \\
\cline { 2 - 8 } Organik & Jumlah & $\mathbf{\%}$ & Jumlah & $\mathbf{\%}$ & Jumlah & \% & Jumlah & \% \\
\hline Sayuran & $\mathbf{3 5}$ & $\mathbf{2 7 \%}$ & $\mathbf{4 2}$ & $\mathbf{3 1 \%}$ & $\mathbf{1 0 7}$ & $\mathbf{2 9 \%}$ & 184 & $\mathbf{2 9 \%}$ \\
Buah & 33 & $26 \%$ & 34 & $25 \%$ & 80 & $22 \%$ & 147 & $23 \%$ \\
Biji-bijian & 13 & $10 \%$ & 15 & $11 \%$ & 61 & $16 \%$ & 89 & $14 \%$ \\
Daging & 16 & $12 \%$ & 12 & $9 \%$ & 37 & $10 \%$ & 65 & $10 \%$ \\
Susu & 8 & $6 \%$ & 8 & $6 \%$ & 38 & $10 \%$ & 54 & $9 \%$ \\
Telur & 22 & $17 \%$ & 23 & $17 \%$ & 44 & $12 \%$ & 89 & $14 \%$ \\
Beras & 2 & $2 \%$ & 1 & $1 \%$ & 3 & $1 \%$ & 6 & $1 \%$ \\
Lele & 0 & $0 \%$ & 1 & $1 \%$ & 0 & $0 \%$ & 1 & $0 \%$ \\
\hline Total & 129 & $100 \%$ & 136 & $99 \%$ & 370 & $100 \%$ & 635 & $100 \%$ \\
\hline
\end{tabular}

Pada indikator Quality and Healthy Aspect, generasi Baby Boomers dan generasi Y sangat setuju bahwa makanan organik lebih sehat, sedangkan generasi X menyatakan setuju bahwa makanan organik tidak mempunyai efek yang berbahaya.

Pada indikator External Appearance, generasi Baby Boomers setuju bahwa makanan organik lebih enak dibandingkan makanan biasa, sedangkan generasi $\mathrm{X}$ dan $\mathrm{Y}$ setuju bahwa makanan organik lebih menarik dibandingkan makanan biasa.

Pada indikator Negative Aspect, generasi Baby Boomers sangat setuju bahwa makanan organik lebih baik daripada makanan konvensional. Sedangkan Generasi X dan Y setuju bahwa makanan organik lebih mahal.

Tabel 3. Deskripsi Rata-Rata Variabel Gaya Hidup Sehat dan Sikap terhadap Makanan Organik

\begin{tabular}{lccc}
\hline \multicolumn{1}{c}{ Variabel } & \multicolumn{2}{c}{ Generasi } & \multicolumn{2}{c}{ Baby } & GenerasiGenerasi \\
& Boomers & X & Y \\
\hline Gaya Hidup Sehat & 3,64 & 3,32 & 3,05 \\
Sikap terhadap Makanan & 4,02 & 3,78 & 3,79 \\
Organik & & & \\
\hline
\end{tabular}

Berdasarkan tabel 3, secara keseluruhan generasi Baby Boomers memiliki rata-rata variabel gaya hidup sehat dan sikap terhadap makanan organik yang paling tinggi diantara generasi $\mathrm{X}$ dan $\mathrm{Y}$.

\section{Hasil Analysis of Varians (One Way Anova)}

Untuk menguji perbedaan tiap generasi terhadap variabel gaya hidup sehat dan sikap terhadap makanan organik, maka dilakukan uji One Way Anova. Hasil dari uji One Way Anova yang menggunakan tingkat kepercayaan $95 \%$ dan $\alpha=0,05$ mempunyai kriteria sebagai berikut (Uyanto, 2006):

a. Jika nilai probabilitas signifikansi $>0,05$ maka tidak terdapat perbedaan antara sampel yang diteliti.

b. Jika nilai probabilitas signifikansi $<0,05$ maka terdapat perbedaan antara sampel yang diteliti.

Berdasarkan tabel 4, menunjukkan hasil uji One Way Anova secara keseluruhan untuk variabel gaya hidup sehat dan variabel sikap terhadap makanan organik. Secara keseluruhan terdapat perbedaan antara generasi Baby Boomers, generasi X, dan generasi $\mathrm{Y}$ dalam variabel gaya hidup sehat dan variabel sikap terhadap makanan organik. 
Tabel 4.. Hasil Uji One Way Anova secara Keseluruhan

\begin{tabular}{llccccc}
\hline & & Mean & Std Deviation & F Value & Sig. Value & Perbedaan \\
\hline Gaya Hidup & Generasi Baby Boomers & 3,642 & 0,3631 & 22,532 & 0,000 & Berbeda \\
Sehat & Generasi X & 3,319 & 0,5288 & & & \\
& Generasi Y & 3,053 & 0,5827 & & & \\
& Total & 3,249 & 0,5771 & & & \\
\hline Sikap terhadap & Generasi Baby Boomers & 4,016 & 0,3736 & 3,912 & 0,021 & \\
Makanan & Generasi X & 3,782 & 0,4831 & & & \\
Organik & Generasi Y & 3,791 & 0,5627 & & & \\
& Total & 3,839 & 0,5140 & & & \\
\hline
\end{tabular}

Tabel 5.. Hasil Uji One Way Anova per Indikator

\begin{tabular}{|c|c|c|c|c|c|c|}
\hline & & Mean & Std Deviation & F Value & Sig. Value & Perbedaan \\
\hline Natural Food & Generasi Baby Boomers & 3,684 & 0,5016 & 24,718 & 0,000 & Berbeda \\
\hline \multirow[t]{3}{*}{ Consumption } & Generasi X & 3,333 & 0,6180 & & & \\
\hline & Generasi Y & 2,980 & 0,6453 & & & \\
\hline & Total & 3,222 & 0,6713 & & & \\
\hline \multirow[t]{4}{*}{ Health Care } & Generasi Baby Boomers & 3,300 & 0,6362 & 14,851 & 0,000 & Berbeda \\
\hline & Generasi X & 2,920 & 0,6727 & & & \\
\hline & Generasi Y & 2,597 & 0,8695 & & & \\
\hline & Total & 2,832 & 0,8250 & & & \\
\hline \multirow{4}{*}{ Life Equilibrium } & Generasi Baby Boomers & 4,050 & 0,5997 & 0,819 & 0,442 & Tidak berbeda \\
\hline & Generasi X & 3,880 & 0,7264 & & & \\
\hline & Generasi Y & 3,921 & 0,7587 & & & \\
\hline & Total & 3,940 & 0,7179 & & & \\
\hline Quality and & Generasi Baby Boomers & 4,407 & 0,4327 & 5,697 & 0,004 & Berbeda \\
\hline \multirow[t]{3}{*}{ Healthy Aspect } & Generasi X & 4,062 & 0,6280 & & & \\
\hline & Generasi Y & 4,075 & 0,6798 & & & \\
\hline & Total & 4,146 & 0,6334 & & & \\
\hline External & Generasi Baby Boomers & 3,910 & 0,7121 & 6,763 & 0,001 & Berbeda \\
\hline \multirow[t]{3}{*}{ Appearance } & Generasi X & 3,611 & 0,8049 & & & \\
\hline & Generasi Y & 3,404 & 0,8728 & & & \\
\hline & Total & 3,567 & 0,8444 & & & \\
\hline \multirow[t]{4}{*}{ Negative Aspect } & Generasi Baby Boomers & 3,775 & 0,4111 & 0,868 & 0,421 & Tidak berbeda \\
\hline & Generasi X & 3,657 & 0,4432 & & & \\
\hline & Generasi Y & 3,771 & 0,6479 & & & \\
\hline & Total & 3,744 & 0,5570 & & & \\
\hline
\end{tabular}

Berdasarkan tabel 5 , diketahui bahwa generasi Baby Boomers, generasi X, dan generasi Y dalam variabel gaya hidup sehat, indikator natural food consumption dan health care memiliki perbedaan yang signifikan, namun indikator life equilibrium tidak memiliki perbedaan. Begitu juga dalam variabel sikap terhadap makanan organik, indikator quality and healthy aspect dan external appearance memiliki perbedaan yang signifikan, sedangkan indikator negative aspect tidak memiliki perbedaan. Sehingga dapat disimpulkan indikator yang memiliki perbedaan secara signifikan yaitu, indikator natural food consumption, health care, quality and healthy aspect, dan external appearance.

\section{Hasil Post Hoc Test}

Setelah diketahui adanya perbedaan gaya hidup sehat dan sikap terhadap makanan organik di beberapa indikator melalui uji ANOVA, maka selanjutnya akan dilakukan Post Hoc Test untuk mengetahui dan mencari kelompok generasi mana saja yang memiliki perbedaan signifikan secara detail. Dalam pengujian kali ini, penulis menggunakan metode Tukey sebagai metode Post Hoc Test. Berikut hasil Post Hoc Test gaya hidup sehat dan sikap terhadap makanan organik pada generasi Baby Boomers, generasi $\mathrm{X}$, dan generasi $\mathrm{Y}$. 
Tabel 6. Hasil Post Hoc Test secara Keseluruhan

\begin{tabular}{lccccc}
\hline $\begin{array}{c}\text { Dependent } \\
\text { Variable }\end{array}$ & $(\boldsymbol{I})$ Generasi & $(\boldsymbol{J})$ Generasi & Mean Difference $(\boldsymbol{I}-\boldsymbol{J})$ & Sig. & Berbeda/ Tidak Berbeda \\
\hline Gaya Hidup Sehat & BB & X & $0,3235^{*}$ & 0,006 & Berbeda \\
& & Y & $0,5887^{*}$ & 0,000 & Berbeda \\
& X & BB & $-0,3235^{*}$ & 0,006 & Berbeda \\
& & Y & $0,2652^{*}$ & 0,007 & Berbeda \\
& Y & BB & $-0,5887^{*}$ & 0,000 & Berbeda \\
Sikap terhadap & BB & X & $-0,2652^{*}$ & 0,007 & Berbeda \\
Makanan Organik & & Y & 0,2337 & 0,052 & Tidak berbeda \\
& X & BB & $-0,2337$ & 0,025 & Berbeda \\
& & Y & $-0,0088$ & 0,052 & Tidak berbeda \\
& Y & BB & $-0,2248^{*}$ & 0,994 & Tidak berbeda \\
& & X & 0,0088 & 0,025 & Berbeda \\
\end{tabular}

Tabel 7. Hasil Post Hoc Test per Indikator

\begin{tabular}{|c|c|c|c|c|c|}
\hline $\begin{array}{c}\text { Dependent } \\
\text { Variable }\end{array}$ & (I) Generasi & (J) Generasi & Mean Difference(I-J) & Sig. & Berbeda/ Tidak Berbeda \\
\hline Natural Food & BB & $\mathrm{X}$ & $0,3507 *$ & 0,010 & Berbeda \\
\hline \multirow[t]{5}{*}{ Consumption } & & $\mathrm{Y}$ & $0,7040 *$ & 0,000 & Berbeda \\
\hline & $\mathrm{X}$ & $\mathrm{BB}$ & $-0,3507^{*}$ & 0,010 & Berbeda \\
\hline & & $\mathrm{Y}$ & $0,3533^{*}$ & 0,001 & Berbeda \\
\hline & Y & $\mathrm{BB}$ & $-0,7040 *$ & 0,000 & Berbeda \\
\hline & & $\mathrm{X}$ & $-0,3533^{*}$ & 0,001 & Berbeda \\
\hline \multirow[t]{6}{*}{ Health Care } & BB & $\mathrm{X}$ & $0,3802 *$ & 0,036 & Berbeda \\
\hline & & $\mathrm{Y}$ & $0,7028^{*}$ & 0,000 & Berbeda \\
\hline & $\mathrm{X}$ & $\mathrm{BB}$ & $-0,3802 *$ & 0,036 & Berbeda \\
\hline & & $\mathrm{Y}$ & $0,3225^{*}$ & 0,032 & Berbeda \\
\hline & Y & $\mathrm{BB}$ & $-0,7028^{*}$ & 0,000 & Berbeda \\
\hline & & $\mathrm{X}$ & $-0,3225^{*}$ & 0,032 & Berbeda \\
\hline Quality and & $\mathrm{BB}$ & $\mathrm{X}$ & $0,3449 *$ & 0,014 & Berbeda \\
\hline \multirow{5}{*}{ Healthy Aspect } & & $\mathrm{Y}$ & $0,3317 *$ & 0,005 & Berbeda \\
\hline & $X$ & $\mathrm{BB}$ & $-0,3449 *$ & 0,014 & Berbeda \\
\hline & & Y & $-0,0133$ & 0,991 & Tidak berbeda \\
\hline & $\mathrm{Y}$ & $\mathrm{BB}$ & $-0,3317 *$ & 0,005 & Berbeda \\
\hline & & $\mathrm{X}$ & 0,0133 & 0,991 & Tidak berbeda \\
\hline External & $\mathrm{BB}$ & $\mathrm{X}$ & 0,2989 & 0,156 & Tidak berbeda \\
\hline \multirow[t]{5}{*}{ Appearance } & & $\mathrm{Y}$ & $0,5058 *$ & 0,001 & Berbeda \\
\hline & $X$ & $\mathrm{BB}$ & $-0,2989$ & 0,156 & Tidak berbeda \\
\hline & & $\mathrm{Y}$ & 0,2069 & 0,277 & Tidak berbeda \\
\hline & Y & $\mathrm{BB}$ & $0,5058^{*}$ & 0,001 & Berbeda \\
\hline & & $X$ & 0,2069 & 0,277 & Tidak berbeda \\
\hline
\end{tabular}

Tabel 6 dan 7 menunjukkan analisa Post Hoc Test yang dijalankan menggunakan metode Tukey. Didapatkan hasil berupa perbedaan rata-rata dan nilai signifikansi dari perbandingan rata-rata ke empat indikator diatas. Perbedaan rata-rata yang diberi tanda bintang (*) menjelaskan bahwa adanya perbedaan yang signifikan antara kedua kelompok generasi. Untuk nilai signifikansi, jika nilai signifikansi lebih kecil daripada 0,05 , maka terdapat perbedaan yang signifikan. Sebaliknya jika nilai signifikansi lebih besar dari 0,05 maka tidak terdapat perbedaan yang signifikan antara kedua kelompok generasi.
Hasil analisa deskriptif rata-rata jawaban responden menunjukkan bahwa masyarakat Surabaya, terutama generasi Baby Boomers menjalani gaya hidup sehat dan memiliki sikap terhadap makanan organik yang lebih positif. Ini di buktikan dengan nilai rata-rata per variabel yang berada pada kategori tinggi. Pada generasi Baby Boomers rata-rata jawaban responden mengenai variabel gaya hidup sehat adalah sebesar 3,64 yang termasuk dalam kategori tinggi. Pada generasi $\mathrm{X}$ rata-rata jawaban responden mengenai variabel gaya hidup sehat adalah sebesar 3,32 yang termasuk dalam kategori netral. Sedangkan pada 
generasi $\mathrm{Y}$, rata-rata jawaban responden mengenai variabel gaya hidup sehat adalah sebesar 3,05 yang berada dalam kategori netral. Dilihat dari rata-rata nilai jawaban responden antar generasi, generasi Baby Boomers memiliki nilai yang lebih tinggi dibandingkan dengan generasi $\mathrm{X}$ dan $\mathrm{Y}$. Sehingga dapat disimpulkan generasi Baby Boomers lebih mempunyai gaya hidup yang sehat dibandingkan generasi $X$ dan Y. Hasil ini didukung oleh Williams \& Page (2011) yang menyatakan bahwa generasi Baby Boomers mementingkan kesehatan dan berusaha untuk mencari alternatif untuk terlihat lebih sehat dan awet muda. Begitu pula dengan variabel sikap terhadap makanan organik, generasi Baby Boomers menunjukkan nilai rata-rata yang lebih tinggi dibandingkan generasi $\mathrm{X}$ dan Y. Dengan nilai rata-rata pada variabel sikap terhadap makanan organik sebesar 4,02 yang berada pada kategori tinggi. Pada generasi $X$, rata-rata nilai pada variabel sikap terhadap makanan organik sebesar 3,78 yang juga berada pada kategori tinggi. Begitu pula dengan generasi $\mathrm{Y}$ yang mempunyai nilai rata-rata sebesar 3,79 yang juga dikategorikan sebagai tinggi. Melihat besaran nilai rata-rata yang dihasilkan responden, dapat disimpulkan bahwa sikap terhadap makanan organik di masyarakat Surabaya terbilang positif/tinggi, terutama pada generasi Baby Boomers yang memiliki nilai rata-rata paling tinggi dibandingkan dengan nilai rata-rata generasi lainnya.

Dalam menjalani gaya hidup sehat, generasi Baby Boomers sangat menghindari untuk mengonsumsi produk makanan yang mengandung bahan kimiawi tambahan. Generasi Baby Boomers juga sering mengonsumsi buah dan sayur dan menghindari mengonsumsi makanan olahan. Generasi X dan Y juga setuju untuk menghindari mengonsumsi produk makanan yang mengandung bahan kimia tambahan, tetapi generasi $\mathrm{X}$ dan $\mathrm{Y}$ cenderung sering mengonsumsi buah dan sayur dalam menjalani gaya hidup sehat. Hal ini sesuai dengan penelitian yang dilakukan oleh Casini et al., (2015) bahwa muncul suatu pola konsumsi baru di generasi $\mathrm{X}$, yang disebut sebagai "healthier consumers". Konsumen dalam segmen ini ditandai dengan tingginya tingkat konsumsi buah dan sayuran, roti dan gandum, tingkat konsumsi ikan yang sedang, dan tingkat konsumsi daging, lemak, alkohol dan makanan manis yang rendah.

Berbeda dengan generasi Baby Boomers, dalam mengonsumsi makanan olahan, generasi $\mathrm{X}$ dan $\mathrm{Y}$ bersikap netral, yang berarti generasi $\mathrm{X}$ dan $\mathrm{Y}$ tidak menghindari dan mungkin saja masih mengonsumsi makanan olahan dalam kehidupan sehari-hari. Hal ini sesuai dengan pernyataan Hunter \& Worsley (2009) bahwa generasi $\mathrm{X}$ dan generasi $\mathrm{Y}$ masih cenderung untuk mengonsumsi makanan beku dan siap saji karena keterbatasan waktu yang dimiliki.
Dalam hal perawatan kesehatan generasi Baby Boomers cenderung sering melakukan pemeriksaan kesehatan secara berkala jika dibandingkan dengan generasi X dan Y. Hal ini sesuai dengan pernyataan Berkowitz \& Schewe (2011) bahwa generasi Baby boomers yang saat ini sudah berada di masa tua akan rela membayar untuk perawatan kesehatan. Sedangkan generasi $\mathrm{X}$ dan $\mathrm{Y}$ cenderung berolahraga secara teratur untuk merawat kesehatan. Hal ini sesuai juga sesuai dengan pernyataan William \& Page (2011) bahwa produk dan jasa yang penting bagi generasi Baby boomers adalah produk yang berkaitan dengan kesehatan tetapi lebih kepada perawatan seperti spa dan botox, sedangkan produk dan jasa yang penting untuk generasi $\mathrm{X}$ dan $\mathrm{Y}$ adalah produk rumah tangga dan peralatan olahraga. Ketiga generasi sama-sama cenderung untuk memiliki hidup yang seimbang.

Menurut hasil rata-rata nilai sikap terhadap makanan organik antara generasi Baby boomers, generasi $\mathrm{X}$ dan generasi $\mathrm{Y}$, masyarakat Surabaya memiliki sikap yang positif. Untuk indikator quality and healthy aspect generasi Baby boomers dan generasi Y merasa makanan organik lebih sehat, sedangkan generasi $\mathrm{X}$ merasa makanan organik tidak mempunyai efek yang berbahaya. Untuk indikator external appearance generasi Baby boomers merasa makanan organik lebih enak, sedangkan generasi $\mathrm{X}$ dan generasi $\mathrm{Y}$ merasa makanan organik lebih menarik. Untuk indikator negative aspect nilai ratarata tertinggi untuk generasi Baby boomers adalah pernyataan bahwa makanan organik lebih baik daripada makanan konvensional, ini menunjukkan keselarasan dari indikator-indikator sebelumnya yaitu generasi Baby boomers setuju bahwa makanan organik lebih sehat dan enak. Sedangkan generasi $X$ dan Y menyatakan bahwa makanan organik lebih mahal. Hal ini dikarenakan generasi Baby Boomers yang saat ini sudah berada pada usia tua cenderung menjaga kesehatan, sehingga generasi ini rela membayar untuk mendapatkan manfaat untuk menjaga kesehatan, generasi ini juga biasanya memiliki penghasilan yang sudah berkecukupan, sedangkan generasi X dan $Y$ masih belum terlalu berorientasi penuh pada masalah kesehatan dan generasi $\mathrm{Y}$ biasanya masih belum memiliki penghasilan, sehingga masih menganggap makanan organik lebih mahal.

Hasil uji Anova secara keseluruhan menunjukkan adanya perbedaan gaya hidup sehat dan sikap terhadap makanan organik antara generasi Baby Boomers, generasi X dan generasi $\mathrm{Y}$ di Surabaya. Hasil ini membuktikan bahwa $\mathrm{H} 1$ dan $\mathrm{H} 2$ dapat diterima. Selain itu, hasil uji Anova per indikator menunjukkan bahwa terdapat perbedaan dan juga tidak terdapat perbedaan antar generasi. Indikator 
yang memiliki perbedaan antara lain adalah indikator natural food consumption, health care, quality and healthy aspect, dan external appearance. Sedangkan indikator yang tidak memiliki perbedaan adalah indikator life equilibrium dan negative aspect.

Menurut Gilley et al., (2015) generasi Baby boomers merupakan generasi yang sibuk dalam bekerja sehingga mengorbankan kehidupan pribadi untuk mencapai kesuksesan. Sedangkan generasi $X$ dan Y mengutamakan keseimbangan dalam hidup dan bekerja. Tetapi menurut hasil uji ANOVA menunjukkan tidak ada perbedaan yang signifikan di antara ketiga generasi. Hal ini dapat disebabkan karena usia generasi Baby boomers yang sudah mulai memasuki masa pensiun, sehingga sudah terlepas dari dunia kerja dan lebih memperhatikan kesehatan, yang berarti tidak bergantung berapapun usianya, setiap individu akan berusaha untuk menjalani hidup yang teratur dan seimbang. Begitu juga dengan sikap terhadap makanan organik dalam hal aspek negatif juga tidak ada perbedaan sikap antar generasi Baby Boomers, generasi $\mathrm{X}$ dan generasi $\mathrm{Y}$.

Melihat lebih dalam indikator yang menunjukkan adanya perbedaan yang signifikan, dapat dilihat dari hasil uji Post Hoc Test. Dari hasil uji Post Hoc Test secara keseluruhan dapat dilihat bahwa variabel gaya hidup sehat memiliki perbedaan yang signifikan antara generasi Baby Boomers, generasi X, dan generasi Y. Tetapi pada variabel sikap terhadap makanan organik hanya terdapat perbedaan yang signifikan antara generasi Baby Boomers dan generasi Y. Antara generasi Baby Boomers dan generasi $\mathrm{X}$ juga antara generasi $\mathrm{X}$ dan generasi $\mathrm{Y}$ tidak memiliki perbedaan pada variabel sikap terhadap makanan organik. Hasil Post Hoc Test per indikator dapat dilihat bahwa dalam indikator natural food consumption dan health care memiliki perbedaan yang signifikan antara generasi Baby Boomers, generasi X, dan generasi Y. Sedangkan pada indikator quality and healthy aspect tidak terdapat perbedaan antara generasi $\mathrm{X}$ dan generasi Y. Pada indikator external appearance juga tidak terdapat perbedaan sikap antara generasi Baby Boomers dengan generasi $\mathrm{X}$, dan generasi $\mathrm{X}$ dengan generasi $\mathrm{Y}$, tetapi ada perbedaan signifikan antara generasi Baby Boomers dan generasi Y.

\section{KESIMPULAN DAN SARAN}

Kesimpulan dari penelitian ini adalah

1. Dari segi profil responden, mayoritas makanan organik yang paling banyak dikonsumsi adalah sayuran dan buah. Mayoritas responden membeli makanan organik di supermarket dan mengonsumsinya minimal 1 minggu sekali.
2. Hal yang paling dilakukan generasi Baby Boomers dalam menjalani gaya hidup sehat adalah dengan menghindari mengonsumsi produk makanan yang mengandung bahan kimia tambahan, melakukan pemeriksaan kesehatan secara berkala dan mencoba untuk memiliki gaya hidup yang teratur.

3. Hal yang paling dilakukan generasi $\mathrm{X}$ dalam menjalani gaya hidup sehat adalah dengan sering mengonsumsi buah dan sayur, berolahraga secara teratur, dan mencoba menyeimbangkan antara pekerjaan dan kehidupan pribadi.

4. Hal yang paling dilakukan generasi $\mathrm{Y}$ dalam menjalani gaya hidup sehat adalah dengan sering mengonsumsi buah dan sayur, berolahraga secara teratur, dan mencoba memiliki gaya hidup yang teratur.

5. Menurut generasi Baby boomers makanan organik lebih sehat, enak dan lebih baik daripada makanan konvensional. Sedangkan generasi $\mathrm{X}$ dan generasi $\mathrm{Y}$ merasa makanan organik tidak memiliki efek yang berbahaya, lebih sehat, lebih menarik dan lebih mahal.

6. Generasi Baby Boomers, generasi $\mathrm{X}$ dan generasi Y menunjukkan sikap yang positif terhadap makanan organik. Mayoritas responden dari tiap generasi menunjukkan minat untuk membeli ulang makanan organik walaupun makanan organik dirasa lebih mahal daripada makanan konvensional.

7. Generasi Baby Boomers merupakan generasi yang lebih menjalani gaya hidup sehat dibandingkan generasi lainnya. Generasi Baby Boomers juga merupakan generasi yang memiliki sikap paling positif terhadap makanan organik. Generasi Baby Boomers setuju bahwa makanan organik lebih sehat, lebih enak, dan lebih baik daripada makanan konvensional.

8. Terdapat perbedaan gaya hidup sehat dan sikap terhadap makanan organik antara generasi Baby Boomers, generasi X, dan generasi Y di Surabaya.

9. Pada variabel gaya hidup sehat, terdapat perbedaan pada indikator natural food consumption dan indikator health care, pada variabel sikap terhadap makanan organik, terdapat perbedaan pada indikator quality and healthy aspect dan external appearance. Sedangkan indikator yang tidak memiliki perbedaan yang signifikan adalah indikator life equilibrium dari variabel gaya hidup sehat dan indikator negative aspect pada variabel sikap terhadap makanan organik.

Berdasarkan hasil penelitian, maka saran yang diberikan adalah: 
1. Industri bisnis yang bergelut dalam bidang makanan organik dapat lebih gencar dalam memperkenalkan jenis makanan organik lainnya selain sayuran dan buah kepada masyarakat sekitar, sehingga masyarakat memiliki pengetahuan bahwa makanan organik tidak sebatas buah dan sayur.

2. Dengan melihat bagaimana gaya hidup sehat yang dilakukan tiap generasi, industri bisnis dan para pemasar dapat menentukan pendekatan yang tepat untuk menawarkan produk atau jasa yang sesuai. Sebagai contoh, generasi Baby Boomers cenderung menghindari makanan yang mengandung bahan kimia tambahan dan cenderung melakukan pemeriksaan kesehatan secara berkala, maka produk dan jasa yang dapat ditawarkan bisa berupa makanan yang bebas dari pengawet dan pewarna untuk menarik minat konsumen generasi Baby Boomers, juga rangkaian jasa yang berkaitan dengan pelayanan kesehatan, seperti menawarkan membership dalam suatu pusat pelayanan pemeriksaan kesehatan. Sedangkan untuk generasi $X$ dan generasi $\mathrm{Y}$ yang cenderung berolahraga bisa ditawarkan membership pusat kebugaran (gym).

3. Nilai rata-rata variabel sikap terhadap makanan organik pada ketiga generasi dapat dibilang cukup tinggi, ini berarti responden yang sudah pernah mengonsumsi makanan organik, mayoritas mempunyai sikap yang positif. Oleh karena itu pemasar tidak perlu takut dan ragu untuk memperkenalkan makanan organik ke masyarakat yang belum pernah mengonsumsi contoh dengan memperkenalkan wrapping salad, mix salad dengan berbagai macam dreasing.

4. Bagi penelitian selanjutnya, dapat melakukan penelitian di kota lain atau pada generasi lain selain generasi Baby Boomers, generasi X dan generasi $\mathrm{Y}$.

\section{DAFTAR REFERENSI}

Berkowitz, E.N. \& Schewe, C.D. (2011). Generational cohorts hold the key to understanding patients and health care providers: Coming-ofage experiences influence health care behaviors for a lifetime. Health Marketing Quartely, 28(2), 190-204.

Blair, R. (2012). Organic production and food quality. USA: A John Wiley \& Sons, Ltd., Publications.

Casini, L., Contini, C., Romano, C., \& Scozzafava, G. (2015). Trends in food consumptions: what is happening to generation X?. British Food Journal, 117(2), 705-718.
Chen, M.F. (2009). Attitude toward organic foods among taiwanese as related to health consciousness, environmental attitudes, and the mediating effects of a healthy lifestyle. British Food Journal, 111(2), 165-178.

Didno. (2017, April 22). Gerakan Masyarakat Hidup Sehat berawal dari diri sendiri. Kompasiana. Retrieved September 11, 2018, from http://www. kompasiana.com/didno76/gerakan-masyarakathidup-sehat-berawal-dari-diri-sendiri_58fada822 7b0bd6006622421

Dimitri, C. \& Dettmann, R.L. (2012). Organic food consumers: what do we really know about them?. British Food Journal, 114(8), 11571183.

Divine, R.L. \& Lepisto, L. (2005). Analysis of the healthy lifestyle consumer. Journal of Consumer Marketing, 275-283.

Gil, J.M., Gracia, A. \&Sanchez, M. (2000). Market segmentation and willingness to pay for organic products in Spain. International Food and Agribusiness Management Review, 3(2), 207-26.

Gilley, A., Waddell, K., Hall, A., Jackson, S.A., \& Gilley, J.W. (2015). Manager behavior, generation, and influence on work-life balance: An empirical investigation. The Journal of Applied Management and Entrepreneurship, 20(1), 3-23.

Hawkins, Del.I., \& Mothersbaugh, David L. (2010). Consumer behaviour: Building marketing strategy (11th ed). New York: McGraw-Hill, Irwin.

Hunter, W. \& Worsley, T. (2009). Understanding the older food consumer: present day behaviours and future expectations. Appetite, 52(1), 147-54.

Kapoor, C. \& Solomon, N. (2011). Understanding and managing generational differences in the workplace. Worldwide Hospitality and Tourism Themes, 3(4), 308-318.

Kotler, P., \& Amstrong, G. (2016). Principles of marketing (16th ed). USA: Pearson Education Limited.

Lancaster, L.C., \& Stillman, D. (2002). When Generations Collide. Who They Are. Why They Clash. How to Solve the Generational Puzzle at Work. New York: Collins Business.

Ntanos, A., Michalis, S., \& Ntanos, S. (2014). Millennial consumers' perceptions on the organic products. 9th eRA International Scientific Conference, Piraeus, 26-35.

Paul, J. \& Rana, J. (2012). Consumer behavior and purchase intention for organic food. Journal of Consumer Marketing, 29(6), 412-422.

Rafikasari, D. (2018, March 9). Kesadaran masyarakat Indonesia terhadap kesehatan kian meningkat. SindoNews. Retrieved September 12, 2018, 
from https://lifestyle.sindonews.com/read/1288 163/155/kesadaran-masyarakat-indonesia-terhadap-kesehatan-kian-meningkat-1520557457

Schiffman, L.G. \& Kanuk, L.L. (2007). Consumer behaviour (9th ed). New Jersey: Pearson Education, Inc.
Williams, K.C. \& Page, R.A. (2011). Marketing to the generation. Journal of Behavioral Studies in Business, 3(3), 1-17.

World Health Organization. (1999). Health living: What is a healthy lifestyle?. Copenhagen: WHO Regional Office for Europe. 